ing's own terms this response scarcely makes sense, given that it doesn't explain why it would be wrong to defer to present scientists who have reached agreement on how the experiments work. But even more worrying is his taking the objection seriously in the first place. After all, why should it count against an independently plausible thesis that it threatens the selfrespect of sociologists of science?

I suspect that this kind of professional anxiety accounts for many of the moves made by Pickering and his colleagues in the sociology of science. They resist views, like scientific realism, which they see as threats to their professional status. Unfortunately, this kind of thinking is unlikely to carry any weight outside the sociological profession. Outsiders may wish to sympathize with the sociologists' lack of self-confidence, but they will have little reason to be persuaded of their views.

David Papineau is in the Department of Philosophy, King's College London, Strand, London WC2R 2LS, UK.

\section{The healing arts}

\author{
Alexander G. Bearn
}

Genes, Blood and Courage: A Boy Called Immortal Sword. By David G. Nathan. Harvard University Press: 1995. Pp. 276. $\$ 24.95$, £15.95.

THE hippocratic oath, always taken more seriously in the United States than in the United Kingdom, enjoins physicians to refrain from discussing the ills of their patients in public. There has never been, however, a shortage of physician-writers who used their medical background to dramatize the relationship between doctors and their patients. The names of A. J. Cronin, Francis Brett Young and Arthur Conan Doyle quickly come to mind. Somerset Maugham, in his last major work Summing $U p$, reflected on the importance of his clinical experience in his writing:

I saw how men died. I saw how they bore pain. I saw what hope looked like, fear and relief; I saw the dark lines that despair drew on a face; I saw courage and steadfastness. I saw faith shine in the eyes of those who trusted in what I could only think was an illusion, and I saw the gallantry that made a man greet the prognosis of death with an ironic joke because he was too proud to let those about him see the terror of his soul.

The self-imposed convention of silence was dramatically breached in 1962 when Lord Moran decided to discuss Winston Churchill's medical problems. His book, Churchill: The Diaries of Lord Moran, evoked a barrage of criticism from the profession, as Richard Lovell, in his recent biography, Churchill's Doctor, makes abundantly clear.

During the past 30 years, however, the perception that doctors should remain silent about the diseases of their patients has altered. Perhaps the most startling medical revelations related to the changing state of President Eisenhower's bowels, which held the American public suitably enthralled. This was in marked contrast to Lord Dawson of Penn's laconic bulletin on King George V: "The King's life is moving peacefully towards its close".

In Genes, Blood and Courage, the distinguished paediatric physician and clinical investigator David Nathan provides a riveting account of a young boy who was first seen by Nathan at the Children's Hospital in Boston at the age of 10 . Astute clinical and haematological investigation rapidly disclosed that Dayan Saif (a pseudonym to preserve strict confidentiality), of Arab extraction, was suffering from thalassaemia major, an inherited disease notoriously difficult to treat and one that often leads to an early death. When the book ends, Dayan is 30 and has weathered the physical and psychological vicissitudes of his disease by Nathan's rare combination of high professional competence and sustained compassion.

The story told so well is a moving account of the 30-year struggle to keep Dayan alive physically and spiritually in the face of a prognosis of grim proportions. It is one of the many virtues of Nathan's book that he uses Dayan as a poignant example of the increasing importance of the molecular revolution in the treatment of human diseases, particularly those such as thalassaemia that are of genetic origin.

Nathan tells the dramatic story of how the development of a new iron-chelating agent made possible the elimination of excess iron from Dayan's body, the inevitable consequence of many lifesaving blood transfusions. The reversal of heart failure caused by accumulation of iron in the heart, by Desferal, was an important therapeutic advance. Moreover, the development of molecular biological techniques has now simplified prenatal diagnosis by allowing the sampling of fetal skin or placental cells. Nathan, who has contributed greatly to our knowledge of the thalassaemias, has made the case for science - more and more science - in our understanding and treatment of human disease immensely compelling. At the same time, the inspiring Samaritan role of a caring physician suffuses the book. This medical and scientific drama is so engagingly written that to open the pages will ensure its reading.

Throughout the book, Nathan refers to many contemporary leaders in science and medicine, particularly those concerned with unravelling haematological disease. At times his enthusiastic admiration for his colleagues leads him to such hyperbole that those referred to may justifiably experience twinges of personal embarrassment.

There is no doubt that Nathan has written a remarkable book that demonstrates the compatibility, indeed necessity, of combining hard science, medical technology and human compassion. The peaks and valleys of emotion that accompany success and failure in the treatment of chronic disease have never been better described. His account highlights over and over again that clinical investigation, anchored firmly in molecular biology, will inevitably lead to better understanding of human disease.

Alexander G. Bearn is at the Rockefeller University, 1230 York Avenue, New York, New York 10021-6399, USA.

\section{Triumph in adversity}

\section{Hugh Freeman}

An Anthropologist on Mars: Seven Paradoxical Tales. By Oliver Sacks. Knopf/Picador: 1995. Pp. 328. \$24, $£ 15.99$ (hbk); $£ 6.99$ (pbk).

Memory's Ghost: The Strange Tale of Mr. $M$ and the Nature of Memory. by Philip J. Hilts. Simon and Schuster: 1995. Pp. 253, \$22.

WITH the progress of scientific medicine, the 'anecdotal case' has acquired an increasingly bad name, and it is particularly anathematized in the current movement for 'evidence-based' practice. Yet the very unusual patient has always had an essential role in getting doctors to shift their framework of thought about how both the body and the mind work. For the past 20 years, Oliver Sacks has demonstrated in book after book the enormous value that still attaches to that natural experiment involving some rare abnormality of the nervous system. These "seven paradoxical tales" show that the seam is far from exhausted.

If the cases have a fairly constant theme, it is the surprisingly nonmechanical plasticity of the nervous system in responding to changed needs. The artist who became totally colour-blind, for instance, at first found himself in an "alien, incoherent, and almost nightmarish world". Yet as time passed, his new landscape of greys took on a strange fascination and even beauty; he began to see "a world of pure form". His head 